\title{
Assessment of Nannochloropsis gaditana growth and lipid accumulation with increased inorganic carbon delivery
}

\section{Authors: Todd C. Pederson, R. D. Gardner, Robin Gerlach, and Brent M. Peyton}

The final publication is available at Springer via http://dx.doi.org/10.1007/s10811-018-1470-x.

Pedersen TC, RD Gardner, R Gerlach, BM Peyton, "Assessment of Nannochloropsis gaditana growth and lipid accumulation with increased inorganic carbon delivery," Journal of Applied Phycology, April 2018; 1-12. doi: 10.1007/s10811-018-1470-x. 


\title{
Assessment of Nannochloropsis gaditana growth and lipid accumulation with increased inorganic carbon delivery
}

\author{
Todd C. Pedersen \& Robert D. Gardner \& Robin Gerlach \& Brent M. Peyton
}

Algal biomass refineries for sustainable transportation fuels, in particular biodiesel, will benefit from algal strain en-hancements to improve biomass and lipid productivity. Specifically, the supply of inorganic carbon to microalgal cultures represents an area of great interest due to the potential for improved growth of microalgae and the possibility for incorporation with $\mathrm{CO}_{2}$ mitigation processes.

Combinations of bicarbonate $\left(\mathrm{HCO}_{3}{ }^{-}\right)$salt addition and application of $\mathrm{CO}_{2}$ to control $\mathrm{pH}$ have shown compelling increases in growth rate and lipid productivity of fresh water algae. Here, focus

was placed on the marine organism, Nannochloropsis gaditana, to investigate growth and lipid accumulation under various strategies of enhanced inorganic carbon supply. Three gas application strategies were investigated: con-tinuous sparging of atmospheric air, continuous sparging of 5\%

$\mathrm{CO}_{2}$ during light hours until nitrogen depletion, and continuous sparging of atmospheric air supplemented with $5 \% \mathrm{CO}_{2}$ for $\mathrm{pH}$ control between 8.0 and 8.3. These gas sparging schemes were combined with addition of low concentrations $(5 \mathrm{mM})$ of sodium bicarbonate at inoculation and high concentration $(50 \mathrm{mM})$ of sodium bicarbonate amendments just prior to nitrogen depletion. The optimum scenario observed for growth of $\mathrm{N}$. gaditana under these inorganic carbon conditions

was controlling $\mathrm{pH}$ with $5 \% \mathrm{CO}_{2}$ on demand, which increased both growth rate and lipid accumulation. Fatty acid methyl esters were primarily comprised of C16:0 (palmitic) and C16:1 (palmitoleic) aliphatic chains. Additionally, the use of high concentration $(50 \mathrm{mM})$ of bicarbonate amendments further improved lipid content (up to 48.6\%) under nitrogen deplete conditions when paired with $\mathrm{pH}$-controlled strategies.

Non-renewable fossil fuels have contributed to anthropogenic climate change and as a result, the use of these ener-gy sources should be significantly slowed to reduce the net emission of greenhouse gases. In 2015, the overall contri-bution from liquid biofuels to US primary energy con-sumption was approximately 1\% (Brennan and Owende 2010; Williams and Laurens 2010). Extensive use of fossil fuels in the transportation sector is contributing to carbon dioxide $\left(\mathrm{CO}_{2}\right)$ emissions which are causing detrimental global impacts (Yang and Gao 2003; Lam et al. 2012). Recently, large interest has been placed on the removal or capture of $\mathrm{CO}_{2}$, either chemically or biologically, though it is generally agreed that enhanced biological processes will be the favored choice due to the high energetic and fiscal cost of chemical processes (Kumar et al. 2010; Sydney et al. 2010; Ho et al. 2011). 
One appealing method of enhanced biological $\mathrm{CO}_{2}$ fixation is the use of microalgae (Sawayama et al. 1995; Sydney et al. 2010). Temporary $\mathrm{CO}_{2}$ sequestration in biomass is an attractive process because atmospheric carbon is recycled in an active cycle of biofuel production from biomass and subsequent combustion of that biomass, resulting in nominal additional $\mathrm{CO}_{2}$ production (Kumar et al. 2010; Lam et al. 2012) and the biological conversion of $\mathrm{CO}_{2}$ has relatively low energy requirements. Biofuels produced from microalgal biomass have potential to contribute to the increasing global demand for liquid fuels (Chisti 2008; Davis et al. 2011). For biofuel production, microalgae have distinct advantages over terrestrial plants which are outlined in numerous reviews ( $\mathrm{Hu}$ et al. 2008; Schenk et al. 2008; Amin 2009; Lardon et al. 2009; Bhateria and Dhaka 2015). Next to sunlight and water, which are relatively available if an appropriate location for algal cultivation is chosen, inorganic carbon is the next most important substrate for algal growth (Fields et al. 2014; Markou et al. 2014). Microalgae are capable of fixing inorganic carbon from atmospheric $\mathrm{CO}_{2}$, exhaust gases with increased $\mathrm{CO}_{2}$ concentrations, and in solutions of soluble bicarbonate (Kumar et al. 2010; Sydney et al. 2010), which lends this ability to various strategies for supplementing the necessary inorganic carbon (Brennan and Owende 2010; Davis et al. 2011; Chi et al. 2011, 2013). Despite the advantages afforded by microalgae, relatively high consumption of energy, water, and nutrients has thus far made algal biofuels economically unfavorable (Williams and Laurens 2010; Markou et al. 2014).

Research focusing on upstream growth and production of algal biomass will be pivotal to the realization of algal biofuels. Strain selection has been highlighted as one of the main areas for improvement (Mata et al. 2010; Ahmad et al. 2011), with specific focus placed on high lipid content strains (Griffiths and Harrison 2009). Optimization of species with industrial relevance, as well as screening newly identified strains for favorable characteristics, make up a substantial portion of work being done in this field. One such industrially relevant strain is Nannochloropsis gaditana. Previous work on $N$. gaditana has provided useful insights for culturing characteristics with regard to enhancements in growth and lipid content. There is a general consensus that lipid accumulation is improved under nitrogen deplete conditions (Simionato et al. 2013; Ren and Ogden 2014; Hallenbeck et al. 2015), while other culturing conditions have been reported to have different effects. One study revealed improved growth using $40 \mathrm{mM}$ Tris- $\mathrm{HCl}$ for $\mathrm{pH}$ control (Rocha et al. 2003), indicating that $\mathrm{pH}$-controlled strategies may be beneficial, although the use of expensive organic buffers may not be realistic at industrial scale. Another study reported culture densities as high as $15.5 \mathrm{~g} \mathrm{~L}^{-1}$ with the use of additional $\mathrm{CO}_{2}$ supplementation $(4.5 \%)$ under conditions of optimized light and culture inoculum (Hallenbeck et al. 2015). Other researchers have demonstrated steady-state continuous growth of $N$. gaditana with
pH-controlled strategies using $\mathrm{CO}_{2}$ and obtained productivities of $0.42 \mathrm{~g} \mathrm{~L}^{-1}$ day $^{-1}$ (Camacho-Rodríguez et al. 2015). Additionally, the genome of $N$. gaditana was recently published (Radakovits et al. 2012). While the genome sequence was not used in this research, the work presented here could have potential to lend itself to future work exploiting a genetic understanding of $N$. gaditana (e.g., transcriptomics or qPCR). Research on $N$. gaditana will likely be reinvigorated as advancements are made in the genetics and physiology of the alga. Other members of the Nannochloropsis genus have also been studied by Ma et al. (2014) who observed that N. gaditana obtained similar biomass productivity compared to their top performer, Nannochloropsis oceanica (IMET1), but $N$. gaditana demonstrated less overall lipid content, resulting in a lower value feedstock for biofuel production. To date, $N$. gaditana has not been reported to be the most outstanding species with respect to lipid productivity; however, it accurately reflects characteristics of Eustigmatophyceae and is a model organism to study under conditions of enhanced carbon delivery.

Lipid accumulation under nitrogen deplete conditions has been studied with marine Nannochloropsis species for extended periods (Dong et al. 2013), and in other marine species, enhancements under increased carbon supplementation have been demonstrated (Guihéneuf and Stengel 2013). Additional work has shown compelling results for the use of bicarbonate salts in lipid promoting strategies (Gardner et al. 2012, 2013a; White et al. 2013), and a recent study demonstrated enhanced biomass growth in the chlorophyte Chlorella vulgaris (Lohman et al. 2015). These results have highlighted the need for additional research focused on the effects of enhanced carbon supplementation on the physiology of a larger portfolio of organisms. In this study, inorganic carbon was provided to $N$. gaditana cultures through increased $\mathrm{CO}_{2}$ concentrations in sparge gas, addition of bicarbonate $\left(\mathrm{HCO}_{3}{ }^{-}\right)$salt to the culture medium, and combinations of these methods. This served to obtain fundamental observations on the culturing characteristics of $N$. gaditana. Growth was monitored throughout nitrogen replete and deplete conditions, and lipid accumulation was monitored after nitrogen depletion.

\section{Materials and methods}

\section{Strain, experimental, and culturing conditions}

Nannochloropsis gaditana strain CCMP526 was obtained from the National Center for Marine Algae and Microbiota and was cultured in $\mathrm{ASP}_{\mathrm{II}}$ medium (Provasoli et al. 1957). Total alkalinity for each condition was estimated using $\mathrm{pH}$ data, and accounting for contributions from initial bicarbonate additions and bicarbonate additions at nitrate depletion; results are presented in Supplementary Table 1. Total change in 
alkalinity from nitrate consumption was also considered. For each condition, one of the three fixed gas supply strategies were used: (i) continuous sparge of atmospheric air; (ii) continuous sparge of atmospheric air supplemented with $5 \% \mathrm{CO}_{2}$ $(v / v)$ during light hours until nitrogen depletion; and (iii) continuous sparge of atmospheric air supplemented with $5 \% \mathrm{CO}_{2}$ $(v / v)$ as needed to maintain $\mathrm{pH}$ between 8.0 and 8.3. Bicarbonate additions were performed for some treatments and were accomplished in one of the two ways: (i) addition of $5 \mathrm{mM} \mathrm{NaHCO}_{3}$ initially with inoculation or (ii) addition of $50 \mathrm{mM} \mathrm{NaHCO}_{3}$ amendment just prior to nitrogen depletion. The experimental conditions are outlined by their various combinations in Table 1.

While 12 conditions would have fulfilled the full factorial design with the fixed effects discussed above, here, a select few conditions are absent. Conditions which were omitted from the experimental design can partially be elicited from data of other conditions and combined for interpretive conclusions to be drawn.

Experiments were conducted in triplicate batch reactors consisting of $70 \times 500 \mathrm{~mm}$ glass tubes containing $1 \mathrm{~L}$ of medium and temperature controlled at $23{ }^{\circ} \mathrm{C} \pm 1{ }^{\circ} \mathrm{C}$ by submersion in circulated water baths. Banks of T5 fluorescent lights were used to provide light $\left(250 \mu \mathrm{mol}\right.$ photons $\left.\mathrm{m}^{-2} \mathrm{~s}^{-1}\right)$ maintained on a $14 \mathrm{~h}: 10 \mathrm{~h}(\mathrm{~L} / \mathrm{D})$ cycle. In experimental conditions utilizing sodium bicarbonate, analytical grade $\mathrm{NaHCO}_{3}$ was used (Fisher Chemical, USA). Sparge gas $\left(0.4 \mathrm{~L} \mathrm{~min}^{-1}\right)$ was humidified by bubbling through Nalgene bottles containing ultrapure $(18.2 \Omega)$ deionized water $\left(\mathrm{diH}_{2} \mathrm{O}\right)$ and controlled using individual rotameters for each condition with gas supply outlined as above.

\section{Analysis of culture and medium components}

Cell concentrations were determined using an optical hemocytometer with a minimum of 400 cells counted per sample. A standard benchtop $\mathrm{pH}$ meter was used to measure sample $\mathrm{pH}$. Nitrate was measured using the colorimetric assay based on the Szechrome NAS reagent (Polysciences Inc., USA). For each sample, $20 \mu \mathrm{L}$ of $0.2 \mu \mathrm{m}$ filtered culture was combined in a 96-well plate with $200 \mu \mathrm{L}$ of Szechrome reagent and thoroughly mixed. After 30 min of incubation at room temperature, the absorbance was read at $570 \mathrm{~nm}$ and nitrate concentrations were determined using a six-point calibration curve.

\section{Chlorophyll measurements}

Chlorophylls and carotenoids were determined using a heat-based methanol extraction method, modified from Ördög et al. (2012). Briefly, $1 \mathrm{~mL}$ of culture was centrifuged at $6000 \times \mathrm{g}$ for $10 \mathrm{~min}$ and the supernatant separated. One milliliter of methanol was added to the remaining pellet and the extract was sonicated for $15 \mathrm{~s}$. Immediately after, the mixture was exposed to $70^{\circ} \mathrm{C}$ for $5 \mathrm{~min}$ and then centrifuged again at the same conditions as above. Absorbance of the supernatant was read at 666, 653, and $470 \mathrm{~nm}$. Chlorophyll calculations were carried out according to equations described by Ördög et al. (2012).

\section{Harvesting}

Samples were collected just prior to nitrogen depletion and at the end of each experiment, which was selected to be $72 \mathrm{~h}$ after nitrogen depletion. For each sample, $50 \mathrm{~mL}$ of culture was centrifuged (Thermo Scientific, Sorvall Legend XTR, USA) at $4816 \times g$ for $10 \mathrm{~min}$ at $4{ }^{\circ} \mathrm{C}$. Cultures were resuspended in $35 \mathrm{~mL}$ of $\mathrm{diH}_{2} \mathrm{O}$ to rinse the cultures of medium salts and bicarbonate. Samples were again centrifuged as before, the residual water removed, and the algae promptly frozen. The resulting algal pellets were lyophilized until remaining water was removed.

Table 1 Experimental design for assessment of $N$. gaditana growth and lipid accumulation under various carbon application strategies

\begin{tabular}{|c|c|c|c|c|c|}
\hline & \multicolumn{3}{|c|}{ Air/gas delivery } & \multicolumn{2}{|c|}{$\mathrm{NaHCO}_{3}$ amendments } \\
\hline & $\begin{array}{l}\text { Continuous } \\
\text { atmospheric }\end{array}$ & $\begin{array}{l}\text { Continuous } 5 \% \\
\mathrm{CO}_{2}\end{array}$ & $\begin{array}{l}\mathrm{pH} \text { controlled } \\
(8.0 \text { to } 8.3)\end{array}$ & $\begin{array}{l}\text { Initial } \\
{[5 \mathrm{mM}]}\end{array}$ & $\begin{array}{l}\text { Near nitrogen depletion } \\
{[50 \mathrm{mM}]}\end{array}$ \\
\hline Air-1 & $\mathrm{x}$ & & & $\mathrm{N}$ & $\mathrm{N}$ \\
\hline Air-2 & $\mathrm{x}$ & & & $\mathrm{N}$ & $\mathrm{Y}$ \\
\hline Air-3 & $\mathrm{x}$ & & & $\mathrm{Y}$ & $\mathrm{Y}$ \\
\hline $\mathrm{CO}_{2}-1$ & & $\mathrm{x}$ & & $\mathrm{N}$ & $\mathrm{N}$ \\
\hline $\mathrm{CO}_{2}-2$ & & & $\mathrm{x}$ & $\mathrm{N}$ & $\mathrm{N}$ \\
\hline $\mathrm{CO}_{2} / \mathrm{HCO}_{3}-1$ & & & $\mathrm{x}$ & $\mathrm{N}$ & Y \\
\hline $\mathrm{CO}_{2} / \mathrm{HCO}_{3}-2 / 3$ & & & $\mathrm{x}$ & $\mathrm{Y}$ & $\mathrm{Y}$ \\
\hline $\mathrm{CO}_{2} / \mathrm{HCO}_{3}-4$ & & $\mathrm{x}$ & & $\mathrm{Y}$ & $\mathrm{N}$ \\
\hline $\mathrm{CO}_{2} / \mathrm{HCO}_{3}-5$ & & $\mathrm{x}$ & & $\mathrm{N}$ & $\mathrm{Y}$ \\
\hline
\end{tabular}




\section{Transesterification for fatty acid methyl ester analysis}

Samples were transesterified using a previously described protocol (Lohman et al. 2013) with minor modifications. Approximately $30 \mathrm{mg}$ of lyophilized algal biomass was transferred to a 15-mL Pyrex test tube with a Teflon lined screw cap (Kimble-Chase, USA). One milliliter of toluene and $2 \mathrm{~mL}$ of sodium methoxide (Fisher Scientific, USA) were added to each sample. Samples were heated in an oven for $30 \mathrm{~min}$ at $90{ }^{\circ} \mathrm{C}$ and vortexed every $10 \mathrm{~min}$. After cooling to room temperature, $2 \mathrm{~mL}$ of $14 \%$ boron tri-fluoride in methanol (Sigma-Aldrich, USA) was added to each sample, and samples were heated for $30 \mathrm{~min}$ at $90{ }^{\circ} \mathrm{C}$, vortexing every $10 \mathrm{~min}$. Samples were again allowed to cool before $0.8 \mathrm{~mL}$ of hexane and $0.8 \mathrm{~mL}$ of a saturated salt water solution $\left(\mathrm{NaCl}\right.$ in $\left.\mathrm{diH}_{2} \mathrm{O}\right)$ were added. To facilitate fatty acid methyl ester (FAME) partitioning, samples were heated for $10 \mathrm{~min}$ at $90{ }^{\circ} \mathrm{C}$, vortexed for $10 \mathrm{~s}$, and centrifuged at $1200 \times g$ for $2 \mathrm{~min}$ to enhance phase separation. One milliliter of the organic phase was removed from the top layer using a gas-tight syringe and transferred to a 2-mL GC vial for gas chromatography-mass spectrometry (GC-MS) analysis.

\section{GC-MS analysis}

GC-MS analysis was performed as previously described (Lohman et al. 2013). Briefly, $1 \mu \mathrm{L}$ split (2:1) injections were performed using an autosampler into a GC-MS (Agilent 6890 N GC and Agilent 5973 Networked MSD) equipped with a $30 \mathrm{~m} \times 0.25 \mathrm{~mm} \times 0.15 \mathrm{~mm}$ Agilent DB-23 column $(0.25 \mu \mathrm{m}$ phase thickness). The injector temperature was $240{ }^{\circ} \mathrm{C}$, and the detector temperature was $150{ }^{\circ} \mathrm{C}$. The initial column temperature of $50^{\circ} \mathrm{C}$ was held for $1 \mathrm{~min}$, increased to $175^{\circ} \mathrm{C}$ at a rate of $25^{\circ} \mathrm{C} \mathrm{min}^{-1}$, and immediately followed by a ramp at $4{ }^{\circ} \mathrm{C} \min ^{-1}$ to a final temperature of $230{ }^{\circ} \mathrm{C}$ which was held for $10 \mathrm{~min}$ before termination of the run. The carrier gas was ultra-high purity helium and was run in constant pressure mode. FAMEs were determined by quantifying each response peak with the nearest eluting calibration standard based on retention time, using MSD ChemStation software (Ver. D.02.00.275). Additional analyses were performed using a custom MATLAB function programmed to align retention times of unknown peaks to standards, as well as discard peaks below the minimum quantification limit. A 28-component FAME standard prepared in methylene chloride (NLEA FAME mixture; Restek, USA) was used for GC-MS retention time identification and response curve generation $\left(R^{2}>0.99\right)$. Regular check standards were included in run sequences to validate calibration curves for the duration of the sequence and samples were re-analyzed if check standards were outside of $5 \%$ relative difference.

\section{Calculations}

Equation 1 was used to calculate specific growth $(\mu)$ rate during the time interval estimated for uninhibited exponential growth:

$\mu=\frac{\left(\ln \left(X_{2}\right)-\ln \left(X_{1}\right)\right)}{\left(t_{2}-t_{1}\right)} t_{2}>t_{1}$

Biomass productivity $(P)$ was calculated with Eq. 2 over the duration of the experiment:

$P=\frac{\left(X_{2}-X_{1}\right)}{\left(t_{2}-t_{1}\right)} \quad t_{2}>t_{1}$

where $X_{1}$ and $X_{2}$ refer to biomass concentrations (cells $\mathrm{mL}^{-1}$ or $\mathrm{g} \mathrm{L}^{-1}$ ) at time points $t_{1}$ and $t_{2}$, respectively.

\section{Statistics}

Results are expressed as data means $\pm 95 \%$ confidence interval $(\mathrm{CI})$ assuming a Student's $t$ distribution $(n=3)$ and were calculated using Excel 2013 and the CONFIDENCE. T function. Multiple comparison tests were performed using Minitab (v 17.3.1) using two-sided confidence intervals with a 95\% confidence level $(\alpha=0.05)$. Tukey's comparison for statistical grouping was performed assuming equal variances. Data means that do not share a letter are significantly different.

\section{Results and discussion}

\section{Cell growth and culture density for different carbon supplementation strategies}

Recent findings using the freshwater microalga $C$. vulgaris demonstrated enhanced growth with low concentration bicarbonate supplementation (Lohman et al. 2015). Increased inorganic carbon delivery $\left(\sim 2 \% \mathrm{CO}_{2}\right)$ has been utilized for growth of the marine organism N. gaditana (Radakovits et al. 2012; Ma et al. 2014), but a comprehensive study investigating various carbon delivery strategies and additional bicarbonate supplementation has not been reported. Therefore, experiments were conducted to test the efficacy of this method on a marine species. Initially, experiments were designed to investigate carbon delivery strategies of air, $\mathrm{CO}_{2}$, and $\mathrm{HCO}_{3}{ }^{-}$supplementation, each individually, and characterize the resulting effects on cell concentration [cells $\mathrm{mL}^{-1}$ ], culture $\mathrm{pH}$, cell dry weight (CDW) $\left[\mathrm{g} \mathrm{L}^{-1}\right]$, chlorophyll content $\left[\mathrm{mg} \mathrm{L}^{-1}\right]$, and biomass productivity $\left[\mathrm{g} \mathrm{L}^{-1} \mathrm{day}^{-1}\right.$ ]. Nitrate was also monitored for timing of bicarbonate amendment in conditions investigating this carbon delivery method for lipid enhancement (Gardner et al. 2012). An illustration of these time-dependent data are shown in Fig. 1 by comparison of condition Air-1 to $\mathrm{CO}_{2} /$ 
Fig. 1 Growth [cells $\mathrm{mL}^{-1}$ ] (a), $\mathrm{pH}(\mathbf{b})$, nitrate concentration $\left[\mathrm{mg} \mathrm{NO}_{3}{ }^{-} \mathrm{N} \mathrm{L}^{-1}\right](\mathbf{c})$, and total chlorophyll concentration $\left[\mathrm{mg} \mathrm{L}^{-1}\right]$ (d) of cultures of $N$. gaditana cultured under different carbon

supplementation strategies. Air-1: continuous sparge of atmospheric air (white triangle). $\mathrm{CO}_{2} / \mathrm{HCO}_{3}-3$ : $\mathrm{pH}$ control (8.0 to 8.3 ) with $5 \mathrm{mM}$ initial $\mathrm{NaHCO}_{3}$ and an additional $50 \mathrm{mM} \mathrm{NaHCO}_{3}$ just prior to nitrogen depletion (white diamond). Time of nitrate depletion is indicated in Table 2. Error bars represent $\pm 95 \% \mathrm{CI}$ $(n=3)$
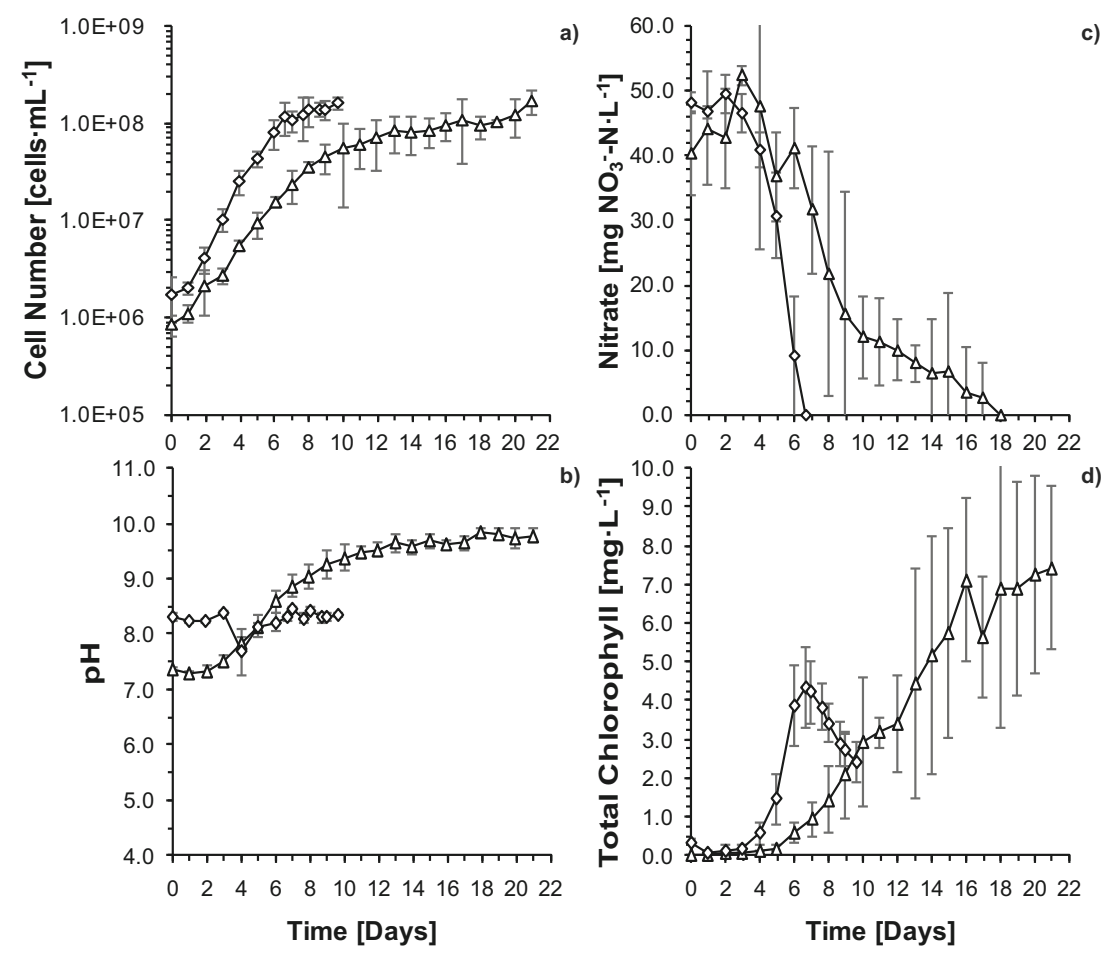

$\mathrm{HCO}_{3}-3$, whereas data from all conditions has been analogously formatted and presented in Electronic Supplementary Figures 1-4. To investigate the use of atmospheric air for carbon delivery, three conditions were investigated: (Air-1), (Air-2), and (Air-3), which are outlined in Table 1. Growth rate and biomass productivity data from $N$. gaditana cultures are visualized in Fig. 2 and data collected at nitrogen depletion and harvest can be seen in Table 2. Time course data is available in Electronic Supplementary Figure 1.

Cultures sparged with atmospheric air only (Air-1 and Air2) experienced a statistically different grouping (e) for growth rate $(\mu)$ when compared to cultures supplemented with an initial $5 \mathrm{mM} \mathrm{HCO}$ amendment (Air-3), which grouped as statistically different ( $c$ and $d$ ). The same result was not true
Fig. 2 Specific growth rate $\left[\right.$ day $^{-1}$ ] (a) and biomass productivity $\left[\mathrm{g} \mathrm{L}^{-1}\right.$ day $\left.^{-1}\right]$ (b) of cultures of $N$. gaditana grown under strategies outlined in Table 1. All specific growth rates were calculated for uninhibited growth during exponential phase and all productivity values were calculated for the duration of the experiment (i.e., from inoculation until final harvest). Error bars represent $\pm 95 \%$ CI $(n=3)$

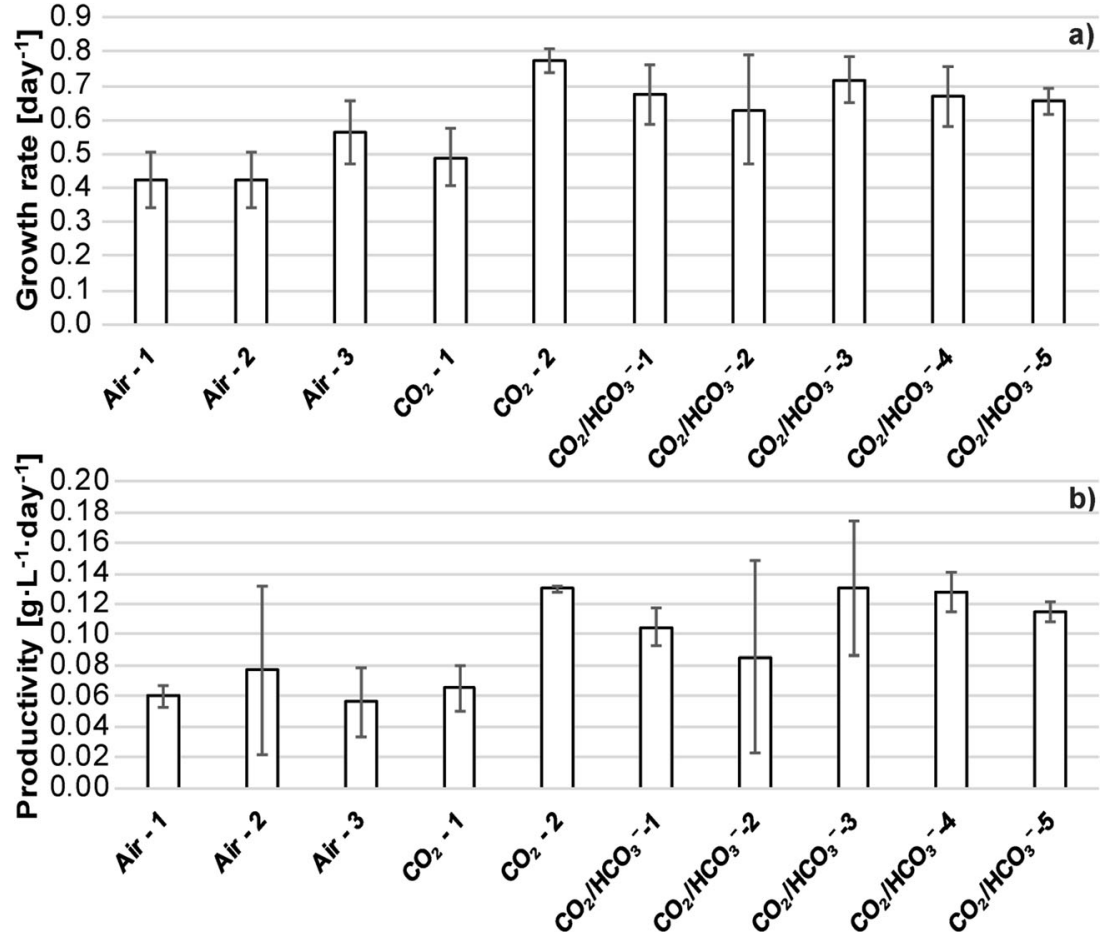


Table $2 N$. gaditana total chlorophyll content $\left[\mathrm{mg} \mathrm{L}^{-1}\right]$ and cell dry weight $(\mathrm{CDW})\left[\mathrm{g} \mathrm{L}^{-1}\right]$ at both nitrogen depletion and harvest (72 $\mathrm{h}$ post depletion) when grown utilizing various carbon delivery methods

\begin{tabular}{|c|c|c|c|c|c|c|}
\hline Test & Aeration & $\begin{array}{l}\text { Time of } \mathrm{NO}_{3}{ }^{-} \\
\text {depletion [day] }\end{array}$ & $\begin{array}{l}\text { Total chlorophyll } \\
{\left[\mathrm{mg} \mathrm{L}^{-1}\right]}\end{array}$ & $\begin{array}{l}\text { Cell dry } \\
\text { weight }\left[\mathrm{g} \mathrm{L}^{-1}\right]\end{array}$ & $\begin{array}{l}\text { Total chlorophyll } \\
{\left[\mathrm{mg} \mathrm{L}^{-1}\right]}\end{array}$ & $\begin{array}{l}\text { Cell dry } \\
\text { weight }\left[\mathrm{g} \mathrm{L}^{-1}\right]\end{array}$ \\
\hline & & & Nitrate depletion & & Harvest & \\
\hline Air-1 & Air & 18 & $6.70 \pm 1.21^{\mathrm{a}}$ & $0.75 \pm 0.18^{\mathrm{a}, \mathrm{b}}$ & $7.41 \pm 2.11^{\mathrm{a}}$ & $1.26 \pm 0.14^{\mathrm{a}, \mathrm{b}}$ \\
\hline Air-2 & $\mathrm{Air} \rightarrow \mathrm{HCO}_{3}^{-}$ & 18 & $6.70 \pm 1.21^{\mathrm{a}}$ & $0.75 \pm 0.18^{\mathrm{a}, \mathrm{b}}$ & $4.77 \pm 0.43^{\mathrm{b}}$ & $1.62 \pm 1.15^{\mathrm{a}}$ \\
\hline Air-3 & $\mathrm{Air}+\mathrm{HCO}_{3}^{-} \rightarrow \mathrm{HCO}_{3}^{-}$ & 13 & $1.27 \pm 0.42^{\mathrm{c}}$ & $0.83 \pm 0.20^{\mathrm{a}, \mathrm{b}}$ & $1.08 \pm 1.66^{\mathrm{d}}$ & $0.90 \pm 0.36^{\mathrm{b}}$ \\
\hline $\mathrm{CO}_{2}-1$ & $5 \% \mathrm{CO}_{2} \rightarrow$ Air & 14 & $3.44 \pm 1.95^{\mathrm{b}}$ & - & $2.93 \pm 2.56^{\mathrm{b}, \mathrm{c}, \mathrm{d}}$ & $1.17 \pm 0.27^{\mathrm{a}, \mathrm{b}}$ \\
\hline $\mathrm{CO}_{2}-2$ & Air $+5 \% \mathrm{CO}_{2}$ on demand ( $\mathrm{pH}$ controlled) & 6.6 & $4.78 \pm 0.60^{\mathrm{b}, \mathrm{c}}$ & $0.65 \pm 0.07^{\mathrm{b}}$ & $2.22 \pm 0.52^{\mathrm{c}, \mathrm{d}}$ & $1.25 \pm 0.02^{\mathrm{a}, \mathrm{b}}$ \\
\hline $\mathrm{CO}_{2} / \mathrm{HCO}_{3}^{-}-1$ & $\begin{array}{l}\mathrm{pH} \text { controlled } \\
\mathrm{HCO}_{3}^{-}\end{array} \rightarrow \mathrm{pH}$ controlled $+50 \mathrm{mM}$ & 10 & $6.74 \pm 2.72^{\mathrm{a}}$ & $0.93 \pm 0.12^{\mathrm{a}}$ & $4.04 \pm 2.63^{\mathrm{b}, \mathrm{c}}$ & $1.36 \pm 0.16^{\mathrm{a}, \mathrm{b}}$ \\
\hline $\mathrm{CO}_{2} / \mathrm{HCO}_{3}{ }^{-}-2$ & $\begin{array}{l}\mathrm{pH} \text { controlled }+5 \mathrm{mM} \mathrm{HCO}_{3}^{-} \rightarrow \mathrm{pH} \\
\text { controlled }+50 \mathrm{mM} \mathrm{HCO}_{3}^{-}\end{array}$ & 10 & $6.12 \pm 2.84^{\mathrm{a}}$ & $0.80 \pm 0.44^{\mathrm{a}, \mathrm{b}}$ & $2.45 \pm 4.23^{\mathrm{b}, \mathrm{c}, \mathrm{d}}$ & $1.11 \pm 0.81^{\mathrm{a}, \mathrm{b}}$ \\
\hline $\mathrm{CO}_{2} / \mathrm{HCO}_{3}{ }^{-}-3$ & $\begin{array}{l}\mathrm{pH} \text { controlled + } 5 \mathrm{mM} \mathrm{HCO}_{3}^{-} \rightarrow \mathrm{pH} \\
\text { controlled }+50 \mathrm{mM} \mathrm{HCO}_{3}^{-}\end{array}$ & 6.6 & $4.35 \pm 1.04^{\mathrm{b}}$ & $0.61 \pm 0.09^{\mathrm{b}}$ & $2.41 \pm 0.50^{\mathrm{c}, \mathrm{d}}$ & $1.26 \pm 0.43^{\mathrm{a}, \mathrm{b}}$ \\
\hline $\mathrm{CO}_{2} / \mathrm{HCO}_{3}{ }^{-}-4$ & $5 \% \mathrm{CO}_{2}+5 \mathrm{mM} \mathrm{HCO}_{3}^{-} \rightarrow$ Air & 7 & $3.11 \pm 1.11^{\mathrm{b}, \mathrm{c}}$ & $0.76 \pm 0.10^{\mathrm{a}, \mathrm{b}}$ & $2.22 \pm 0.26^{\mathrm{c}, \mathrm{d}}$ & $1.28 \pm 0.13^{\mathrm{a}, \mathrm{b}}$ \\
\hline $\mathrm{CO}_{2} / \mathrm{HCO}_{3}{ }^{-}-5$ & $5 \% \mathrm{CO}_{2}+\rightarrow$ Air $+50 \mathrm{mM} \mathrm{HCO}_{3}^{-}$ & 7 & $3.21 \pm 0.51^{\mathrm{b}}$ & $0.68 \pm 0.16^{\mathrm{b}}$ & $1.68 \pm 0.26^{\mathrm{d}}$ & $1.22 \pm 0.07^{\mathrm{a}, \mathrm{b}}$ \\
\hline
\end{tabular}

All values reported as average $\pm 95 \% \mathrm{CI}(n=3)$. Time of nitrate depletion is concomitant with $50 \mathrm{mM}$ bicarbonate amendments for those respective treatments as well as for $\mathrm{CO}_{2}$ shutoff. Cell dry weight (CDW) was determined gravimetrically from lyophilized biomass. Different superscripts indicate differences between the treatments (ANOVA, Tukey's range test, $\alpha=0.05$ ). Data means that do not share a letter are significantly different

of biomass productivity. These conditions achieved similar CDW when compared at nitrate depletion and grouped together statistically at this point ( $\mathrm{a}$ and $\mathrm{b}$ ); however, when compared at harvest, Air-3 grouped as statistically different than Air-2 (a vs. b). The lengthy time requirement for growth with atmospheric air alone ( $\sim 20$ days) was not conducive to high productivity in a batch system. Conditions Air-1 and Air-2 had low initial alkalinity, primarily due to the low concentration of $\mathrm{CO}_{2}$ in atmospheric air $\left(\mathrm{pCO}_{2} \sim 0.0004\right)$. The major contribution to alkalinity in these conditions throughout the course of the experiment stemmed from generation of hydroxyl ions due to nitrate consumption. Maximum specific growth rate was improved with initial supplementation of bicarbonate; however, in Air-3, the initial addition of $5 \mathrm{mM} \mathrm{NaHCO}$ increased the overall alkalinity and contributed to a fairly rapid increase in $\mathrm{pH}$. It is suspected that the relative increase in $\mathrm{CO}_{3}{ }^{2-}$ (which is not readily available for photosynthesis) (Markou et al. 2014) and an unfavorable $\mathrm{pH}(>10.3)$ hindered this condition more than Air-1 or Air-2.

Common strategies for increasing inorganic carbon delivery are supplementation with $\mathrm{CO}_{2}$ in varying concentrations, either continuously or on demand ( $\mathrm{pH}$ control), or supplementation with bicarbonate salts (Gardner et al. 2012; Gardner et al. 2013b; Pancha et al. 2015). To investigate carbon addition strategies incorporating only $\mathrm{CO}_{2}$ delivery, two conditions with a fixed concentration of $\mathrm{CO}_{2}$ were investigated: $\left(\mathrm{CO}_{2}-1\right)$ and $\left(\mathrm{CO}_{2}-2\right)$, which are outlined in Table 1. Growth rates and biomass productivities from $N$. gaditana cultures are shown in Fig. 2, and data collected at nitrogen depletion and harvest are summarized in Table 2. Time course data are available in Electronic Supplementary Figure 2.
Cultures supplemented continuously with $\mathrm{CO}_{2}\left(\mathrm{CO}_{2}-1\right)$ had a statistically different growth rate ( $\mathrm{d}$ and e) relative to cultures supplemented with $5 \% \mathrm{CO}_{2}$ for $\mathrm{pH}$ control $\left(\mathrm{CO}_{2}-2\right)$, which were in group (a). The same result was true of biomass productivity, $\mathrm{CO}_{2}-1$ averaging $0.07 \pm 0.01 \mathrm{~g} \mathrm{~L}^{-1} \mathrm{day}^{-1}$ (c), while $\mathrm{CO}_{2}-2$ averaged $0.13 \pm 0.00 \mathrm{~g} \mathrm{~L}^{-1} \mathrm{day}^{-1}$ (a). Meanwhile, CDW for both cultures at harvest were not statistically different, with $\mathrm{CO}_{2}-1$ and $\mathrm{CO}_{2}-2$ grouping together at harvest. However, the increase in CDW between nitrogen depletion and harvest $\left(72 \mathrm{~h}\right.$ ) for $\mathrm{CO}_{2}-2$ was from $0.65 \pm 0.07$ to $1.25 \pm 0.02 \mathrm{~g} \mathrm{~L}^{-1}$, indicating that $\mathrm{pH}$ control after nitrogen depletion enhanced biomass concentration.

The constant sparging with $5 \% \mathrm{CO}_{2}$ resulted in lower $\mathrm{pH}$ for $\mathrm{CO}_{2}-1$ compared to $\mathrm{CO}_{2}-2$, resulting in lower solubility for inorganic carbon and decreased overall alkalinity. As alkalinity increased due to the consumption of nitrate, there was a systematic shift toward higher bicarbonate concentrations in the systems which likely resulted in an increase in growth rate. For $\mathrm{CO}_{2}$-2, alkalinity was driven up during the experiment which allowed the inorganic carbon pool to remain high, primarily as $\mathrm{HCO}_{3}{ }^{-}$.

Building on the first set of experiments, combinations of carbon delivery strategies were tested to further improve growth rate and productivity. Four combinations of enhanced carbon delivery were tested and are outlined in Table 1; time course results are available in Electronic Supplementary Figures 3 and 4, while presented data from Fig. 2 and Table 2 are discussed. The conditions of $\mathrm{CO}_{2} / \mathrm{HCO}_{3}-2$ and $\mathrm{CO}_{2} / \mathrm{HCO}_{3}-3$ were the same; however, they were run independently to replicate experimental conditions. Of the four treatments tested, all shared at least one statistical grouping 
(b) for growth rate. Further, conditions $\mathrm{CO}_{2}-2, \mathrm{CO}_{2} / \mathrm{HCO}_{3}-1$, and $\mathrm{CO}_{2} / \mathrm{HCO}_{3}-3$ (grown with $\mathrm{pH}$ control) shared a statistical grouping (a), demonstrating that additional supplementation of bicarbonate at inoculum was no better than $\mathrm{pH}$-controlled conditions alone for improving the growth rate. Final cell density of cultures at harvest shared statistical groupings (a and b), but were not all similar at nitrate depletion. At nitrate depletion, $\mathrm{CO}_{2} / \mathrm{HCO}_{3}-1,2$, and 4 shared a statistical grouping (a), while $\mathrm{CO}_{2} / \mathrm{HCO}_{3}-2$ and $\mathrm{CO}_{2} / \mathrm{HCO}_{3}-4$ also shared a different statistical grouping (b). These observations showed that $\mathrm{CO}_{2} / \mathrm{HCO}_{3}-1$ could only be shown to be statistically different from $\mathrm{CO}_{2} / \mathrm{HCO}_{3}-3$ and $\mathrm{CO}_{2} / \mathrm{HCO}_{3}-5$ at nitrate depletion.

Biomass productivities were also observed to vary among the combination of conditions. Statistical grouping of biomass productivity spanned three groups $(\mathrm{a}-\mathrm{c})$, with $\mathrm{CO}_{2} / \mathrm{HCO}_{3}-3$, and $\mathrm{CO}_{2} / \mathrm{HCO}_{3}-4$ group (a) showing the highest productivities of $0.13 \pm 0.04$, and $0.13 \pm 0.01 \mathrm{~g} \mathrm{~L}^{-1}$ day $^{-1}$, respectively. $\mathrm{CO}_{2} / \mathrm{HCO}_{3}-2$ showed the lowest productivity in these treatments, $0.09 \pm 0.05 \mathrm{~g} \mathrm{~L}^{-1} \mathrm{day}^{-1}$, and was the only combination condition to share grouping (c). Since final CDW at harvest could not be statistically separated among the top performing treatments $\left(\mathrm{CO}_{2}-2\right.$ and $\mathrm{CO}_{2} / \mathrm{HCO}_{3}-1, \mathrm{CO}_{2} / \mathrm{HCO}_{3}-2, \mathrm{CO}_{2} /$ $\mathrm{HCO}_{3}-3, \mathrm{CO}_{2} / \mathrm{HCO}_{3}-4$, and $\mathrm{CO}_{2} / \mathrm{HCO}_{3}-5$ ), it is suggested that consideration be placed on improvements to growth rate for faster biomass generation. Treatments which utilized $\mathrm{pH}$ control demonstrated the most improvement in growth rate over carbon supplementation from air; thus, $\mathrm{pH}$ control appears to be sufficient by itself to improve the nutrient replete culturing of $N$. gaditana.

As observed in $\mathrm{CO}_{2}-2$, initial hydroxyl alkalinity promoted the sustained uptake of carbon from the $\mathrm{CO}_{2}$ sparge for the pH-controlled conditions, $\mathrm{CO}_{2} / \mathrm{HCO}_{3}-1, \mathrm{CO}_{2} / \mathrm{HCO}_{3}-2, \mathrm{CO}_{2} /$ $\mathrm{HCO}_{3}-3$. Treatments $\mathrm{CO}_{2} / \mathrm{HCO}_{3}-2$ and $\mathrm{CO}_{2} / \mathrm{HCO}_{3}-3$ which began with added alkalinity $\left(5 \mathrm{mM} \mathrm{HCO}_{3}^{-}\right)$maintained biologically available carbon pools (in the form of $\mathrm{CO}_{2}$ and $\mathrm{HCO}_{3}{ }^{-}$) during growth and further on into nitrate deplete conditions; however, this did not appear to be significantly improved over treatments without additional initial alkalinity (e.g., $\mathrm{CO}_{2}-2$ and $\mathrm{CO}_{2} / \mathrm{HCO}_{3}-3$ ). These conditions all demonstrate a beneficial effect of using $\mathrm{pH}$-controlled systems at more alkaline $\mathrm{pH}$, when it is desirable to maintain a biologically available carbon pool both during and post-nitrogen depletion. In contrast, $\mathrm{CO}_{2} / \mathrm{HCO}_{3}-4$, which initially had bicarbonate alkalinity supplied, quickly generated hydroxyl alkalinity, but was not able to maintain an inorganic carbon pool after nitrogen depletion when the $\mathrm{CO}_{2}$ sparge was turned off.

\section{Total chlorophyll accumulation and degradation with varying carbon supplementation}

Total chlorophyll concentration $\left[\mathrm{mg} \mathrm{L}^{-1}\right]$ was also monitored for all conditions and is available in Electronic Supplementary Figures $1-4$, while primary differences between nitrogen depletion and harvest (shown in Table 2) are discussed. Air1 and Air-2 were statistically different (a) at nitrate depletion when compared to Air-3 (c). Cell concentration and CDW in all three conditions reached similar amounts at nitrogen depletion, but significant differences in $\mathrm{pH}$ were encountered between cultures supplemented with $5 \mathrm{mM}$ initial $\mathrm{NaHCO}_{3}$ and those grown only with atmospheric air. Within the first 6 days of culturing Air-3, the $\mathrm{pH}$ had increased to almost 10.5 from a photosynthetically driven $\mathrm{pH}$ rise, whereas Air-1 and Air-2 never increased past $\mathrm{pH} 10$ before nitrogen depletion. Accordingly, after day 6, Air-3 did not continue to accumulate chlorophyll until nitrogen depletion as Air-1 and Air-2 did. The addition of $5 \mathrm{mM} \mathrm{NaHCO}_{3}$ at inoculation appears to be responsible for the initial $\mathrm{pH}$ increase in Air-3 due to the large amount of $\mathrm{HCO}_{3}{ }^{-}$in the inorganic carbon pool. Use of $\mathrm{HCO}_{3}{ }^{-}$ as the primary carbon source results in a build-up of $\mathrm{OH}^{-}$in the cell, which is neutralized by $\mathrm{H}^{+}$uptake (Chi et al. 2011). Air-1 and Air- 2 cultures received their carbon through the ingassing of $\mathrm{CO}_{2}$ from atmospheric air and thus the $\mathrm{pH}$ increase was smaller. This appeared to maintain cellular ability to accumulate chlorophyll whereas cultures in Air-3 seemingly halted additional accumulation of chlorophyll. Both cultures receiving a bicarbonate amendment just prior to nitrogen depletion (Air-2 and Air-3) experienced decreases in chlorophyll concentrations between nitrate depletion and harvest. Cultures with no additional bicarbonate (Air-1) experienced an increase in chlorophyll concentration during this same period.

$\mathrm{CO}_{2}$ gas sparging was effective at inducing chlorophyll accumulation, with $\mathrm{CO}_{2}-1$ reaching $3.44 \pm 1.59 \mathrm{mg} \mathrm{L}^{-1}$ at nitrogen depletion and $\mathrm{CO}_{2}-2$ reaching $4.78 \pm 0.49 \mathrm{mg} \mathrm{L}^{-1}$ at nitrogen depletion. While these shared a statistical grouping (b), there appeared to be improvements to chlorophyll content through $\mathrm{pH}$ control, such that cultures treated with this strategy accumulated more chlorophyll in less time than was observed with continuous $\mathrm{CO}_{2}$ supply $\left(\mathrm{CO}_{2}-1\right)$. Alternatively, there was a statistical decrease in total chlorophyll at harvest when compared to nitrogen depletion for $\mathrm{CO}_{2}-2$, from $4.78 \pm$ 0.49 to $2.22 \pm 0.52 \mathrm{mg} \mathrm{L}^{-1}$. As with Air-2 and Air-3, the presence of increased inorganic carbon under nitrogen deplete conditions caused a degradation of chlorophyll.

Total chlorophyll content at nitrate depletion in cultures with the combination conditions varied, likely owing to the variation in $\mathrm{CDW}$ at this point. Interestingly, $\mathrm{CO}_{2} / \mathrm{HCO}_{3}-4$ only accumulated $3.11 \pm 0.91 \mathrm{mg} \mathrm{L}^{-1}$ and was the only treatment from the combination conditions to be included in the lowest statistical grouping (c) at nitrate depletion. This test implemented $5 \mathrm{mM}$ initial $\mathrm{NaHCO}_{3}$ and continuous sparge of $\mathrm{CO}_{2}$ during light hours. As with Air-3, it appears that the addition of initial $\mathrm{NaHCO}_{3}$ may have had unfavorable effects on the accumulation of chlorophyll under nitrogen replete conditions. However, $\mathrm{CO}_{2} / \mathrm{HCO}_{3}-4$ was also the only combination condition to not receive additional carbon supplementation post-nitrate depletion and, correspondingly, 
experienced the least extent of chlorophyll degradation, from only $3.11 \pm 0.91$ to $2.22 \pm 0.26 \mathrm{mg} \mathrm{L}^{-1}$. All other combination conditions appeared to suffer more consequential losses to chlorophyll content.

\section{Fatty acid methyl ester content}

Both bicarbonate addition after nitrogen depletion and continued $\mathrm{pH}$ control with $\mathrm{CO}_{2}$ after nitrogen depletion led to increased fatty acid content in $N$. gaditana, but the method of carbon supplementation may significantly impact lipid accumulation. Figure 3 visualizes changes in total fatty acid methyl ester (FAME) content and concentration between nitrogen depletion and harvest, while FAME profiles are summarized for the major chain lengths at nitrogen depletion (Table 3) and at harvest (Table 4). In all experiments of this study, cultures grown under $\mathrm{pH}$-controlled $\mathrm{CO}_{2}$ sparging schemes demonstrated the highest lipid content at harvest, reaching similar levels whether supplemented with additional bicarbonate after nitrogen depletion or not. All results in Tables 3 and 4 are reported on a weight FAME per weight dry biomass percentage basis after direct transesterification. As increased growth rates were observed in conditions supplemented with additional inorganic carbon under nitrogen replete conditions, increased lipid accumulation was observed in these same cultures during nitrogen deplete conditions. Meanwhile, cultures grown with atmospheric air only generally experienced no change in lipid content under nitrogen deplete conditions, whether supplemented with additional bicarbonate or not. Cultures grown with atmospheric air only (Air-1 and Air-2) or even with an initial $5 \mathrm{mM} \mathrm{NaHCO} 3$ supplementation (Air3) did not perform well as potential candidates for lipid accumulation. Air-1 and Air-2 accumulated $16.0 \pm 2.1 \%$ (b and c) FAMEs at nitrogen depletion, while Air-3 accumulated 20.0 $\pm 3.1 \%$ ( $\mathrm{a}, \mathrm{b}$, and $\mathrm{c}$ ). These values remained in the lower statistical groupings at harvest, suggesting that cultures grown without additional carbon supplementation resulted in lower lipid accumulation. The $\mathrm{pH}$ of the media in these conditions remained high after nitrogen depletion $(\mathrm{pH}>10)$. The high $\mathrm{pH}$ conditions observed in atmospheric air cultures were likely responsible for the lower lipid accumulation in these treatments.

For cultures grown with $\mathrm{CO}_{2}$-supplemented air, lipid accumulation was greater for $\mathrm{pH}$-controlled conditions $\left(\mathrm{CO}_{2}-2\right)$ as opposed to continuous supply of $\mathrm{CO}_{2}\left(\mathrm{CO}_{2}-1\right)$. At nitrogen depletion, the lipid content for $\mathrm{CO}_{2}-2$ was relatively low, 15.7 $\pm 1.5 \%$ (b and c), yet it dramatically improved at harvest, reaching $40.3 \pm 2.4 \%$ (a and b). Cultures grown continuously with $\mathrm{CO}_{2}\left(\mathrm{CO}_{2}-1\right)$ accumulated less lipid at harvest and demonstrated wide variability, falling into four statistical groupings (b, c, d, and e), suggesting that the lack of carbon supplementation after nitrogen depletion had negative impacts on lipid accumulation. In both conditions, it was observed that fatty acid methyl ester chains of C16:0 (palmitic) and C16:1 (palmitoleic) were the dominant speciation; C18 (octadecanoic) and C20 (eicosanoic) unsaturated chains were present, albeit at substantially lower percentages.

Combinations of carbon delivery strategies $\left(\mathrm{CO}_{2} / \mathrm{HCO}_{3}-1\right.$, $\mathrm{CO}_{2} / \mathrm{HCO}_{3}-2, \mathrm{CO}_{2} / \mathrm{HCO}_{3}-3, \mathrm{CO}_{2} / \mathrm{HCO}_{3}-4$, and $\mathrm{CO}_{2} / \mathrm{HCO}_{3}-$ $5)$ showed results in congruence with the findings from
Fig. 3 FAME content [weight \%] (a) and FAME concentration $\left[\mathrm{mg} \mathrm{L}^{-1}\right]$ (b) of cultures of $N$. gaditana grown under strategies outlined in Table 1 at nitrogen depletion (white bars) and harvest (gray bars). Error bars represent $\pm 95 \%$ CI $(n=3)$

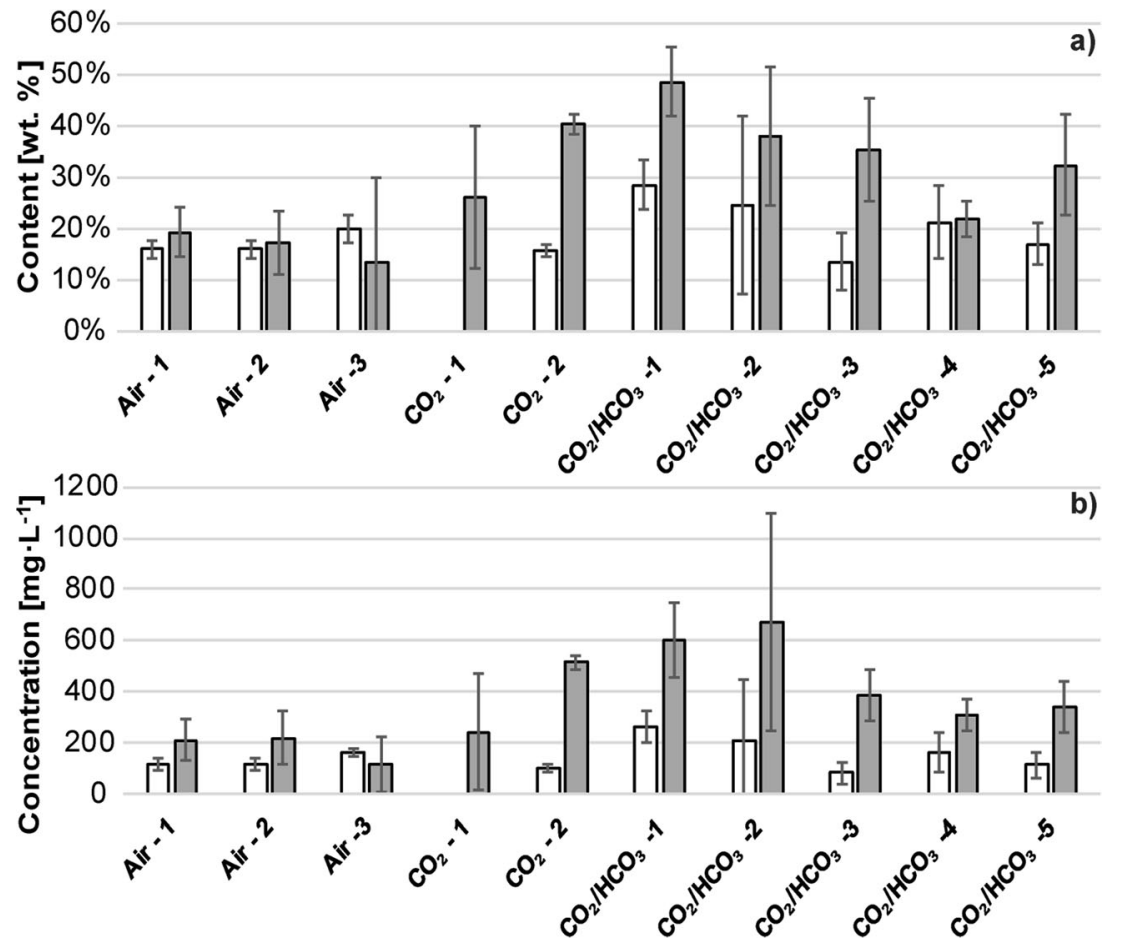


Table 3 N. gaditana FAME profiles for cultures at nitrogen depletion when grown under different carbon delivery methods

\begin{tabular}{|c|c|c|c|c|c|c|}
\hline \multirow[t]{2}{*}{ Treatment } & \multicolumn{5}{|l|}{$\%$ FAME } & \multirow{2}{*}{$\begin{array}{l}\text { Total biodiesel } \\
\text { potential }(\%)\end{array}$} \\
\hline & $\mathrm{C} 16: 0$ & C16:1 & C18:1 & $\mathrm{C} 20: 5$ & Residual & \\
\hline Air-1 & $4.1 \pm 0.6^{\mathrm{c}, \mathrm{d}}$ & $4.9 \pm 0.6^{\mathrm{b}, \mathrm{c}}$ & $1.5 \pm 0.2^{\mathrm{a}, \mathrm{b}}$ & $3.8 \pm 0.6^{\mathrm{d}}$ & $1.7 \pm 0.2^{\mathrm{b}, \mathrm{c}}$ & $16.0 \pm 2.1^{\mathrm{b}, \mathrm{c}}$ \\
\hline Air-2 & $4.1 \pm 0.6^{\mathrm{c}, \mathrm{d}}$ & $4.9 \pm 0.6^{\mathrm{b}, \mathrm{c}}$ & $1.5 \pm 0.2^{\mathrm{a}, \mathrm{b}}$ & $3.8 \pm 0.6^{\mathrm{d}}$ & $1.7 \pm 0.2^{\mathrm{b}, \mathrm{c}}$ & $16.0 \pm 2.1^{\mathrm{b}, \mathrm{c}}$ \\
\hline Air-3 & $6.3 \pm 1.0^{\mathrm{b}, \mathrm{c}, \mathrm{d}}$ & $5.7 \pm 1.0^{\mathrm{a}, \mathrm{b}, \mathrm{c}}$ & $2.2 \pm 0.2^{\mathrm{a}}$ & $3.1 \pm 0.4^{\mathrm{e}}$ & $2.6 \pm 0.5^{\mathrm{a}, \mathrm{b}}$ & $20.0 \pm 3.1^{\mathrm{a}, \mathrm{b}, \mathrm{c}}$ \\
\hline $\mathrm{CO}_{2}-1$ & - & - & - & - & - & - \\
\hline $\mathrm{CO}_{2}-2$ & $4.4 \pm 0.7^{\mathrm{c}, \mathrm{d}}$ & $3.9 \pm 0.3^{\mathrm{b}, \mathrm{c}}$ & $0.1 \pm 0.6^{\mathrm{c}}$ & $5.6 \pm 0.3^{\mathrm{a}}$ & $1.6 \pm 0.3^{\mathrm{b}, \mathrm{c}}$ & $15.7 \pm 1.5^{\mathrm{b}, \mathrm{c}}$ \\
\hline $\mathrm{CO}_{2} / \mathrm{HCO}_{3}^{-}-1$ & $10.5 \pm 2.2^{\mathrm{a}}$ & $8.6 \pm 1.9^{\mathrm{a}}$ & $1.5 \pm 0.5^{\mathrm{a}, \mathrm{b}}$ & $5.3 \pm 0.6^{\mathrm{a}, \mathrm{b}}$ & $2.8 \pm 0.8^{\mathrm{a}}$ & $28.6 \pm 6.1^{\mathrm{a}}$ \\
\hline $\mathrm{CO}_{2} / \mathrm{HCO}_{3}{ }^{-}-2$ & $8.9 \pm 9.2^{\mathrm{a}, \mathrm{b}}$ & $7.3 \pm 7.4^{\mathrm{a}, \mathrm{b}}$ & $1.1 \pm 2.3^{\mathrm{b}, \mathrm{c}}$ & $4.8 \pm 0.7^{\mathrm{b}, \mathrm{c}}$ & $2.5 \pm 1.8^{\mathrm{a}, \mathrm{b}}$ & $24.6 \pm 21.3^{\mathrm{a}, \mathrm{b}}$ \\
\hline $\mathrm{CO}_{2} / \mathrm{HCO}_{3}{ }^{-}{ }^{-} 3$ & $3.5 \pm 2.6^{\mathrm{d}}$ & $3.3 \pm 2.0^{\mathrm{c}}$ & $0.1 \pm 0.6^{\mathrm{c}}$ & $5.4 \pm 0.5^{\mathrm{a}, \mathrm{b}}$ & $1.3 \pm 1.2^{\mathrm{c}}$ & $13.6 \pm 6.7^{\mathrm{c}}$ \\
\hline $\mathrm{CO}_{2} / \mathrm{HCO}_{3}{ }^{-}-4$ & $8.0 \pm 3.9^{\mathrm{a}, \mathrm{b}, \mathrm{c}}$ & $6.7 \pm 3.3^{\mathrm{a}, \mathrm{b}, \mathrm{c}}$ & $0.5 \pm 0.2^{\mathrm{b}, \mathrm{c}}$ & $4.4 \pm 0.4^{\mathrm{c}, \mathrm{d}}$ & $1.7 \pm 1.0^{\mathrm{b}, \mathrm{c}}$ & $21.2 \pm 8.8^{\mathrm{a}, \mathrm{b}, \mathrm{c}}$ \\
\hline $\mathrm{CO}_{2} / \mathrm{HCO}_{3}{ }^{-}-5$ & $5.6 \pm 2.3^{\mathrm{b}, \mathrm{c}, \mathrm{d}}$ & $5.1 \pm 1.8^{\mathrm{b}, \mathrm{c}}$ & $0.3 \pm 0.6^{\mathrm{c}}$ & $4.6 \pm 0.6^{\mathrm{c}}$ & $1.5 \pm 0.8^{\mathrm{c}}$ & $17.1 \pm 5.1^{\mathrm{b}, \mathrm{c}}$ \\
\hline
\end{tabular}

All values reported as average $\pm 95 \% \mathrm{CI}(n=3)$. Values reported as weight $\%$ [g FAME g ${ }^{-1}$ biomass]. Total FAMEs (sum of all quantified FAMEs) [wt $\%$ FAMEs]. Different superscripts indicate differences between the treatments (ANOVA, Tukey's range test, $\alpha=0.05$ ). Data means that do not share a letter are significantly different individual supplementation strategies. In all conditions receiving additional carbon supplementation after nitrogen depletion, a higher FAME content was observed, the highest observed being $48.6 \pm 8.4 \%$ in $\mathrm{CO}_{2} / \mathrm{HCO}_{3}-1$. This treatment was the only one to be placed exclusively in the top statistical grouping (a). Other $\mathrm{pH}$-controlled conditions demonstrated similar improvements to that of $\mathrm{CO}_{2} / \mathrm{HCO}_{3}-1$ from bicarbonate amendments. $\mathrm{CO}_{2} / \mathrm{HCO}_{3}-2$ achieved a lipid content of $38.0 \% \pm 16.4 \%$ at harvest ( $\mathrm{a}$ and $\mathrm{b}$ ), and $\mathrm{CO}_{2} / \mathrm{HCO}_{3}-3$ achieved $35.5 \pm 12.2 \%$ at harvest ( $\mathrm{a}, \mathrm{b}$, and $\mathrm{c}$ ). Furthermore, $\mathrm{CO}_{2} / \mathrm{HCO}_{3}-5$ accumulated $32.4 \pm 9.9 \%$ at harvest (b, c, and d), indicating that continuous carbon supply could be turned off at nitrogen depletion and replaced with a $50 \mathrm{mM} \mathrm{NaHCO}_{3}$ amendment.
These significantly higher total FAME contents demonstrated that enhanced carbon supplementation during nitrogen deplete conditions, be it from $\mathrm{CO}_{2}$ or $\mathrm{HCO}_{3}{ }^{-}$, was beneficial for fatty acid production in $N$. gaditana. The $\mathrm{pH}$-controlled conditions alone $\left(\mathrm{CO}_{2}-2\right)$ also induced accumulation of substantial total FAME, reaching $40.3 \% \pm 2.4 \%$ ( $\mathrm{a}$ and $\mathrm{b}$ ) content at harvest, suggesting that bicarbonate amendment in concert with nitrogen depletion may be a redundant form of carbon delivery; however, the only combination condition which did not receive additional carbon supplementation after nitrogen depletion $\left(\mathrm{CO}_{2} / \mathrm{HCO}_{3}-4\right)$ was also the only combination condition which showed no appreciable increase in FAME content between nitrogen depletion and harvest. This contrasts with $\mathrm{CO}_{2} / \mathrm{HCO}_{3}-5$ which received $50 \mathrm{mM} \mathrm{NaHCO} 3$ after

Table $4 \quad$ N. gaditana FAME profiles for cultures grown under various carbon application strategies at harvest (72 h post-nitrogen depletion)

\begin{tabular}{|c|c|c|c|c|c|c|}
\hline \multirow[t]{2}{*}{ Treatment } & \multicolumn{5}{|l|}{$\%$ FAME } & \multirow[t]{2}{*}{ Total biodiesel potential ( $\%)$} \\
\hline & $\mathrm{C} 16: 0$ & $\mathrm{C} 16: 1$ & $\mathrm{C} 18: 1$ & $\mathrm{C} 20: 5$ & Residual & \\
\hline Air-1 & $5.5 \pm 3.3^{\mathrm{e}, \mathrm{f}}$ & $5.7 \pm 2.3^{\mathrm{d}, \mathrm{e}}$ & $2.2 \pm 1.2^{\mathrm{b}, \mathrm{c}}$ & $3.8 \pm 0.4^{\mathrm{a}}$ & $2.2 \pm 0.4^{\mathrm{b}, \mathrm{c}}$ & $19.3 \pm 6.8^{\mathrm{d}, \mathrm{e}}$ \\
\hline Air-2 & $5.7 \pm 2.6^{\mathrm{e}, \mathrm{f}}$ & $5.5 \pm 2.5^{\mathrm{e}}$ & $1.8 \pm 1.0^{\mathrm{b}, \mathrm{c}}$ & $2.7 \pm 0.7^{\mathrm{a}, \mathrm{b}, \mathrm{c}}$ & $1.7 \pm 0.8^{\mathrm{c}}$ & $17.4 \pm 7.6^{\mathrm{e}}$ \\
\hline Air-3 & $4.8 \pm 7.4^{\mathrm{f}}$ & $4.3 \pm 6.9^{\mathrm{e}}$ & $1.1 \pm 1.6^{\mathrm{c}}$ & $1.7 \pm 2.3^{\mathrm{c}}$ & $1.5 \pm 2.2^{\mathrm{c}}$ & $13.5 \pm 20.4^{\mathrm{e}}$ \\
\hline $\mathrm{CO}_{2}-1$ & $10.6 \pm 8.1^{\mathrm{c}, \mathrm{d}, \mathrm{e}}$ & $8.7 \pm 6.5^{\mathrm{b}, \mathrm{c}, \mathrm{d}, \mathrm{e}}$ & $2.1 \pm 1.6^{\mathrm{b}, \mathrm{c}}$ & $2.3 \pm 0.6^{\mathrm{b}, \mathrm{c}}$ & $2.5 \pm 1.3^{b, c}$ & $26.1 \pm 17.0^{\mathrm{b}, \mathrm{c}, \mathrm{d}, \mathrm{e}}$ \\
\hline $\mathrm{CO}_{2}-2$ & $16.7 \pm 0.5^{\mathrm{a}, \mathrm{b}}$ & $13.7 \pm 0.6^{\mathrm{a}, \mathrm{b}}$ & $2.5 \pm 0.5^{\mathrm{b}, \mathrm{c}}$ & $3.8 \pm 0.5^{\mathrm{a}}$ & $3.6 \pm 0.4^{\mathrm{a}, \mathrm{b}}$ & $40.3 \pm 2.4^{\mathrm{a}, \mathrm{b}}$ \\
\hline $\mathrm{CO}_{2} / \mathrm{HCO}_{3}{ }^{-}-1$ & $19.8 \pm 3.2^{\mathrm{a}}$ & $16.6 \pm 2.7^{\mathrm{a}}$ & $4.5 \pm 0.8^{\mathrm{a}}$ & $3.6 \pm 0.7^{\mathrm{a}}$ & $4.1 \pm 1.0^{\mathrm{a}}$ & $48.6 \pm 8.4^{\mathrm{a}}$ \\
\hline $\mathrm{CO}_{2} / \mathrm{HCO}_{3}{ }^{-}-2$ & $16.0 \pm 5.5^{\mathrm{a}, \mathrm{b}, \mathrm{c}}$ & $12.7 \pm 6.0^{\mathrm{a}, \mathrm{b}}$ & $3.1 \pm 2.8^{\mathrm{a}, \mathrm{b}}$ & $2.7 \pm 1.7^{\mathrm{a}, \mathrm{b}, \mathrm{c}}$ & $3.5 \pm 0.4^{\mathrm{a}, \mathrm{b}}$ & $38.0 \pm 16.4^{\mathrm{a}, \mathrm{b}}$ \\
\hline $\mathrm{CO}_{2} / \mathrm{HCO}_{3}{ }^{-}-3$ & $14.5 \pm 4.5^{\mathrm{a}, \mathrm{b}, \mathrm{c}, \mathrm{d}}$ & $12.3 \pm 4.5^{\mathrm{a}, \mathrm{b}, \mathrm{c}}$ & $2.1 \pm 1.5^{\mathrm{b}, \mathrm{c}}$ & $3.4 \pm 0.8^{\mathrm{a}, \mathrm{b}}$ & $3.2 \pm 1.1^{\mathrm{a}, \mathrm{b}}$ & $35.5 \pm 12.2^{\mathrm{a}, \mathrm{b}, \mathrm{c}}$ \\
\hline $\mathrm{CO}_{2} / \mathrm{HCO}_{3}{ }^{-}-4$ & $9.0 \pm 1.7^{\mathrm{d}, \mathrm{e}, \mathrm{f}}$ & $7.3 \pm 1.7^{\mathrm{c}, \mathrm{d}, \mathrm{e}}$ & $1.3 \pm 0.2^{\mathrm{c}}$ & $2.6 \pm 0.5^{\mathrm{a}, \mathrm{b}, \mathrm{c}}$ & $1.7 \pm 0.3^{\mathrm{c}}$ & $21.9 \pm 4.5^{\mathrm{c}, \mathrm{d}, \mathrm{e}}$ \\
\hline $\mathrm{CO}_{2} / \mathrm{HCO}_{3}{ }^{-}-5$ & $13.5 \pm 4.7^{\mathrm{b}, \mathrm{c}, \mathrm{d}}$ & $11.3 \pm 4.4^{\mathrm{b}, \mathrm{c}, \mathrm{d}}$ & $2.2 \pm 1.5^{\mathrm{b}, \mathrm{c}}$ & $2.8 \pm 0.4^{\mathrm{a}, \mathrm{b}, \mathrm{c}}$ & $2.7 \pm 1.1^{\mathrm{b}, \mathrm{c}}$ & $32.4 \pm 12.1^{\mathrm{b}, \mathrm{c}, \mathrm{d}}$ \\
\hline
\end{tabular}

All values reported as average $\pm 95 \% \mathrm{CI}(n=3)$. Values reported as weight $\%$ [ $\mathrm{g} \mathrm{FAME} \mathrm{g}^{-1}$ biomass]. Total FAMEs (sum of all quantified FAMEs) [wt $\%$ FAMEs]. Different superscripts indicate differences between the treatments (ANOVA, Tukey's range test, $\alpha=0.05$ ). Data means that do not share a letter are significantly different 
nitrogen depletion, when $\mathrm{CO}_{2}$ was shut off, and increased FAME content from $17.1 \pm 5.1 \%$ at nitrogen depletion to $32.4 \pm 12.1 \%$ at harvest. It is difficult to say statistically if the $50 \mathrm{mM} \mathrm{NaHCO} 3$ addition to $\mathrm{CO}_{2} / \mathrm{HCO}_{3}-5$ increased the FAME content, due to the multiple overlap in statistical groups of $\mathrm{CO}_{2} / \mathrm{HCO}_{3}-4$ at both nitrogen depletion and harvest; yet, $\mathrm{CO}_{2} / \mathrm{HCO}_{3}-5$ increased FAME content by an average of $15.3 \%$ during nitrogen deplete conditions, while $\mathrm{CO}_{2} /$ $\mathrm{HCO}_{3}-4$ only increased FAME content by an average of $0.7 \%$ during the same time. Bicarbonate amendment at nitrogen depletion was shown to significantly increase lipid accumulation, and fatty acid chains of $\mathrm{C} 16: 0$ and $\mathrm{C} 16: 1$ were dominant, with $\mathrm{C} 18$ and $\mathrm{C} 20$ unsaturated chains also present, but at substantially lower percentages.

Within the limits of this experimental design, these data suggest that $\mathrm{pH}$-controlled sparging schemes encouraged high lipid productivity in $N$. gaditana, and the timely addition of bicarbonate was also beneficial for improving lipid accumulation. The use of $\mathrm{CO}_{2}$ for $\mathrm{pH}$ control maintained optimal growth of biomass during nitrogen replete conditions, but also supplied enough inorganic carbon for lipid accumulation once nitrogen deplete conditions were reached. These results show that given a large pool of inorganic carbon in concert with nitrogen depletion, substantial lipid accumulation was observed. Additionally, bicarbonate salt supplementation is still largely appealing for improvements in lipid content under nitrogen deplete conditions, especially when no additional carbon is available during this period.

\section{Conclusions}

Cultures of $N$. gaditana were studied for various carbon supplementation strategies to provide direction for improvements with relation to growth and lipid accumulation. The enhanced carbon supplementation strategies studied here demonstrate ways to improve both growth and lipid accumulation in cultures of $N$. gaditana and may prove useful to the implementation of full-scale biofuel production or integrated carbon capture processes.

Specific growth rate and culture density generally increased for cultures which received some form of increased inorganic carbon delivery from $\mathrm{CO}_{2}$ (i.e., $5 \%$ $\mathrm{CO}_{2}$ continuous or on demand), and $5 \mathrm{mM}$ initial $\mathrm{NaHCO}_{3}$ additions showed potential for enhancements to cultures grown with atmospheric air. High $\mathrm{pH}$ conditions yielded unfavorable results and would have to be mitigated; otherwise, culture productivity can be inhibited. In all conditions, CDW was observed to increase at harvest when compared to nitrogen depletion. Initial $5 \mathrm{mM}$ $\mathrm{NaHCO}_{3}$ additions were not observed to be effective for $\mathrm{CDW}$ enhancements of $N$. gaditana cultures for treatments in which additional carbon was already supplemented during nitrogen replete conditions, and could possibly be detrimental to $\mathrm{CDW}$ when paired with $50 \mathrm{mM} \mathrm{NaHCO}$ amendments at nitrogen depletion.

Total chlorophyll accumulation was observed to be faster in $\mathrm{pH}$-controlled cultures during nitrogen replete conditions than continuous $\mathrm{CO}_{2}$ supply or culturing with atmospheric air. Total chlorophyll was generally observed to reach peak concentration near nitrogen depletion, while increased inorganic carbon delivery during nitrogen deplete conditions was observed to induce chlorophyll degradation, which will certainly become a relevant consideration for the optimization of photosynthetic efficiency during lipid accumulation. Under conditions where cellular nitrogen content is fixed, it is feasible that cells could be reallocating nitrogen from chlorophyll during nitrogen deplete conditions. Here, under nitrogen deplete conditions with elevated levels of inorganic carbon, it is thought that the increased uptake of carbon (i.e., increased $\mathrm{C}: \mathrm{N}$ ratios) could have increased the rate of chlorophyll degradation.

Cultures with $\mathrm{pH}$ control largely experienced the most positive effects on lipid content both at harvest and nitrogen depletion, while continuous supply of $\mathrm{CO}_{2}$ showed marginally better FAME accumulation than cultures grown with atmospheric air. Enhanced carbon delivery to cultures, either $\mathrm{CO}_{2}$ gas or $\mathrm{HCO}_{3}{ }^{-}$salts, was shown to have significant effects on growth and lipid accumulation for $N$. gaditana. The best growth scenario observed here was supplementation of $5 \% \mathrm{CO}_{2}$ on demand to control $\mathrm{pH}$. This improved both growth rate and chlorophyll accumulation when compared to cultures grown with atmospheric air or continuous $\mathrm{CO}_{2}$ sparging. With bicarbonate addition, total biodiesel potential was observed as high as $48.6 \% \pm 3.1 \%$, which could be beneficial if production of liquid biofuels is the primary focus. However, due to its marine nature, $N$. gaditana may not be an ideal candidate for alkaline $\mathrm{pH}$ conditions, especially under nitrogen deplete conditions when increased inorganic carbon is present. As shown here, excess inorganic carbon at higher $\mathrm{pH}$ resulted in increased lipid accumulation and appeared to correlate with substantial degradation of chlorophyll, likely leading to decreased photosynthetic efficiency. While the relatively high abundance of C16:0 (palmitic) and C16:1 (palmitoleic) fatty acid chains lend themselves toward biodiesel production, concurrent accumulation of C18:1 (vaccenic) and C20:5 (eicosapentaenoic (EPA)) fatty acid chains could be favorable in nutraceutical applications. Future advancements will have to be made regarding $N$. gaditana beyond the observations here, especially as its genome begins to provide more fundamental knowledge. The results reported here provide more structure to the dynamic field of algal biofuels, with advancements being made concerning everything from growth and production parameters, to economic and environmental modeling. 


\section{Compliance with ethical standards}

Competing interests A patent entitled "Bicarbonate Trigger for Inducing Lipid Accumulation in Algal Systems" (Pat. No 9,096,875) was co-authored by contributing authors Robert D. Gardner and Brent M. Peyton.

\section{References}

Ahmad AL, Yasin NHM, Derek CJC, Lim JK (2011) Microalgae as a sustainable energy source for biodiesel production: a review.

Renew Sust Energy Rev 15:584-593

Amin S (2009) Review on biofuel oil and gas production processes from

microalgae. Energy Convers Manag 50:1834-1840

Bhateria R, Dhaka R (2015) Algae as biofuel. Biofuels 5:607-631

Brennan L, Owende P (2010) Biofuels from microalgae - a review of technologies for production, processing, and extractions of biofuels and co-products. Renew Sust Energy Rev 14:557-577 Camacho-Rodríguez J, Cerón-García MC, Fernández-Sevilla JM,

Molina-Grima E (2015) The influence of culture conditions on biomass and high value product generation by Nannochloropsis gaditana in aquaculture. Algal Res 11:63-73

Chi Z, O'Fallon JV, Chen S (2011) Bicarbonate produced from carbon capture for algae culture. Trends Biotechnol 29:537-541

Chi Z, Xie Y, Elloy F, Zheng Y, Hu Y, Chen S (2013) Bicarbonate-based integrated carbon capture and algae production system with alkalihalophilic cyanobacterium. Bioresour Technol 133:513-521

Chisti Y (2008) Biodiesel from microalgae beats bioethanol. Trends Biotechnol 26:126-131

Davis R, Aden A, Pienkos PT (2011) Techno-economic analysis of autotrophic microalgae for fuel production. Appl Energy 88:3524-3531

Dong H-P, Williams E, Wang DZ, Xie ZX, Hsia RC, Jenck A, Halden R, Li J, Chen F, Place AR (2013) Responses of Nannochloropsis oceanica IMET1 to long-term nitrogen starvation and recovery. Plant Physiol 162:1110-1126

Fields MW, Hise A, Lohman EJ, Bell T, Gardner RD, Corredor L, Moll K, Peyton BM, Characklis GW, Gerlach R (2014) Sources and resources: importance of nutrients, resource allocation, and ecology in microalgal cultivation for lipid accumulation. Appl Microbiol Biotechnol 98:4805-4816

Gardner RD, Cooksey KE, Mus F, Macur R, Moll K, Eustance E, Carlson RP, Gerlach R, Fields MW, Peyton BM (2012) Use of sodium bicarbonate to stimulate triacylglycerol accumulation in the chlorophyte Scenedesmus sp and the diatom Phaeodactylum tricornutum. J Appl Phycol 24:1311-1320

Gardner RD, Lohman E, Gerlach R, Cooksey KE, Peyton BM (2013a) Comparison of $\mathrm{CO}_{2}$ and bicarbonate as inorganic carbon sources for triacylglycerol and starch accumulation in Chlamydomonas reinhardtii. Biotechnol Bioeng 110:87-96
Gardner RD, Lohman EJ, Cooksey KE, Gerlach R, Peyton BM (2013b) Cellular cycling, carbon utilization, and photosynthetic oxygen production during bicarbonate-induced triacylglycerol accumulation in a Scenedesmus sp. Energies 6:6060-6076

Griffiths MJ, Harrison STL (2009) Lipid productivity as a key characteristic for choosing algal species for biodiesel production. J Appl Phycol 21:493-507

Guihéneuf F, Stengel DB (2013) LC-PUFA-enriched oil production by microalgae: accumulation of lipid and triacylglycerols containing n3 LC-PUFA is triggered by nitrogen limitation and inorganic carbon availability in the marine haptophyte Pavlova lutheri. Mar Drugs 11: 4246-4266

Hallenbeck PC, Grogger M, Mraz M, Veverka D (2015) The use of Design of Experiments and Response Surface Methodology to optimize biomass and lipid production by the oleaginous marine green alga, Nannochloropsis gaditana in response to light intensity, inoculum size and $\mathrm{CO}_{2}$. Bioresour Technol 184:161-168

Ho S-H, Chen C-Y, Lee D-J, Chang J-S (2011) Perspectives on microalgal $\mathrm{CO}_{2}$-emission mitigation systems-a review. Biotechnol Adv 29:189-198

Hu Q, Sommerfeld M, Jarvis E, Ghirardi M, Posewitz M, Seibert M, Darzins A (2008) Microalgal triacylglycerols as feedstocks for biofuel production: perspectives and advances. Plant J 54:621-639

Kumar A, Ergas S, Yuan X, Sahu A, Zhang Q, Dewulf J, Malcata FX, van Langenhove $\mathrm{H}$ (2010) Enhanced $\mathrm{CO}_{2}$ fixation and biofuel production via microalgae: recent developments and future directions. Trends Biotechnol 28:371-380

Lam MK, Lee KT, Mohamed AR (2012) Current status and challenges on microalgae-based carbon capture. Int J Greenhouse Gas Control 10: 456-469

Lardon L, Hélias A, Sialve B, Steyer J-P, Bernard O (2009) Life-cycle assessment of biodiesel production from microalgae. Env Sci Technol 43:6475-6481

Lohman EJ, Gardner RD, Halverson L, Macur RE, Peyton BM, Gerlach R (2013) An efficient and scalable extraction and quantification method for algal derived biofuel. J Microbiol Methods 94:235-244

Lohman EJ, Gardner RD, Pedersen T, Peyton BM, Cooksey KE, Gerlach R (2015) Optimized inorganic carbon regime for enhanced growth and lipid accumulation in Chlorella vulgaris. Biotechnol Biofuels 8:82

Ma Y, Wang Z, Yu C, Yin Y, Zhou G (2014) Evaluation of the potential of 9 Nannochloropsis strains for biodiesel production. Bioresour Technol 167:503-509

Markou G, Vandamme D, Muylaert K (2014) Microalgal and cyanobacterial cultivation: the supply of nutrients. Water Res 65: 186-202

Mata TM, Martins AA, Caetano NS (2010) Microalgae for biodiesel production and other applications: a review. Renew Sust Energy Rev 14:217-232

Ördög V, Stirk W, Bálint P, Staden J, Lovász C (2012) Changes in lipid, protein and pigment concentrations in nitrogen-stressed Chlorella minutissima cultures. J Appl Phycol 24:907-914

Pancha I, Chokshi K, Ghosh T, Paliwal C, Maurya R, Mishra S (2015) Bicarbonate supplementation enhanced biofuel production potential as well as nutritional stress mitigation in the microalgae Scenedesmus sp. CCNM 1077. Bioresour Technol 193:315-323

Provasoli L, McLaughlin JJA, Droop MR (1957) The development of artificial media for marine algae. Arch Mikrobiol 25:392-428

Radakovits R, Jinkerson RE, Fuerstenberg SI, Tae H, Settlage RE, Boore JL, Posewitz MC (2012) Draft genome sequence and genetic transformation of the oleaginous alga Nannochloropis gaditana. Nat Commun 3:686.

Ren M, Ogden K (2014) Cultivation of Nannochloropsis gaditana on mixtures of nitrogen sources. Envi Progr Sust Energy 33:551-555

Rocha JM, Garcia JE, Henriques MH (2003) Growth aspects of the marine microalga Nannochloropsis gaditana. Biomol Eng 20:237-242 
Sawayama S, Inoue S, Dote Y, Yokoyama S-Y (1995) $\mathrm{CO}_{2}$ fixation and oil production through microalga. Energy Convers Manag 36:729-731

Schenk PM, Thomas-Hall SR, Stephens E, Marx UC, Mussgnug JH, Posten C, Kruse O, Hankamer B (2008) Second generation biofuels: highefficiency microalgae for biodiesel production. BioEnergy Res 1:20-43

Simionato D, Block MA, La Rocca N, Jouhet J, Maréchal E, Finazzi G, Morosinotto T (2013) The response of Nannochloropsis gaditana to nitrogen starvation includes de novo biosynthesis of triacylglycerols, a decrease of chloroplast galactolipids, and reorganization of the photosynthetic apparatus. Eukaryot Cell 12:665-676

Sydney EB, Sturm W, de Carvalho JC, Thomaz-Soccol V, Larroche C, Pandey A, Soccol CR (2010) Potential carbon dioxide fixation by industrially important microalgae. Bioresour Technol 101:58925896

White D, Pagarette A, Rooks P, Ali S (2013) The effect of sodium bicarbonate supplementation on growth and biochemical composition of marine microalgae cultures. J Appl Phycol 25:153-165

Williams PJB, Laurens LML (2010) Microalgae as biodiesel \& biomass feedstocks: review \& analysis of the biochemistry, energetics \& economics. Energy Environ Sci 3:554

Yang Y, Gao K (2003) Effects of $\mathrm{CO}_{2}$ concentrations on the freshwater microalgae, Chlamydomonas reinhardtii, Chlorella pyrenoidosa and Scenedesmus obliquus (Chlorophyta). J Appl Phycol 15:379-389 